Number 5

\title{
GAMBARAN KADAR ENZIM KOLINESTERASE DALAM DARAH PADA KELOMPOK TANI MEKAR NADI DI DESA BATUNYA KECAMATAN BATURITI
}

\author{
Ni Kadek Meiriana Sari ${ }^{1}$, Nyoman Mastra ${ }^{2}$, Nur Habibah ${ }^{3}$ \\ 1,2,3 Jurusan Analis Kesehatan Poltekkes Denpasar
}

\begin{abstract}
Background: Pesticides is poison and dangerous materials. It can cause negative effects to human health directly or indirectly. Blood cholinesterase enzyme analysis is one of the methods to indicate that someone is poisons by pesticide. The aim of this study is to illustrate the cholinesterase levels in the farmer's blood especially the farmers in Batunya village. Methods: This research is a descriptive study, The population in this research was 30 farmers who are the members of Groups Tani Mekar Nadi. The sampling method that used in this research was saturation sampling. Data collection used the questionnaire. The test-mate-ChE cholinesterase test system (model 400) is the device that used to check the level of cholinesterase in the farmers' blood. Result: The result show that 22 peoples $(73,3 \%)$ cholinesterase level was abnormal. In the other hand, 8 of the farmer $(26,7 \%)$ has normal level of cholinesterase. Conclusion: From the result it can be concluded that it's still important to monitor the level of cholinesterase in farmers' blood to increase awareness towards the danger of pesticide, always use self-protection device, and conducting a good pesticide management.
\end{abstract}

Keywords: pesticide, cholinesterase, poisoned

\section{PENDAHULUAN}

$\begin{array}{ccc}\text { Pestisida secara umum } & \text { produksi pertanian, perkebunan dan } \\ \text { diartikan sebagai bahan kimia } & \text { pemberantasan vektor penyakit. }{ }^{2} \text {. } \\ \text { beracun yang digunakan untuk } & \text { Sebagian besar cara } \\ \text { mengendalikan jasad pengganggu } & \text { penggunaan pestisida oleh petani } \\ \text { yang merugikan manusia. }{ }^{1} & \text { adalah dengan cara penyemprotan. } \\ \text { Pestisida telah digunakan } & \text { Saat penyemprotan merupakan } \\ \text { secara luas untuk meningkatkan } & \text { keadaan dimana petani sangat } \\ & \text { mungkin terpapar bahan kimia yang }\end{array}$

Meditory | ISSN Online : 2549-1520, ISSN Cetak : 2338 - 1159, Vol. 6, No. 2, Desember 2018 HIm. 108 -115, http://ejournal.poltekkes-denpasar.ac.id/index.php/M 
Ni Kadek Meiriana Sari, Dkk., Gambaran Kadar Enzim Kolinesterase Dalam Darah Pada Kelompok Tani Mekar Nadi Di Desa Batunya Kecamatan Baturiti

terdapat dalam pestisida yang digunakan ${ }^{3}$. Menurut data WHO ( dalam Priyanto, 2010), paling tidak ditemukan 20.000 orang meninggal karena keracunan pestisida dan sekitar 5.000 - 10.000 mengalami dampak yang sangat berbahaya seperti kanker, cacat, mandul dan hepatitis dalam setiap tahunnya ${ }^{2}$

Salah satu cara untuk mengetahui keracunan pestisida pada petani adalah dengan melakukan pemeriksaan kadar cholinesterase dalam darah. Kolinesterase adalah enzim yang menghidrolisis dari acetylcholine neurotransmitter (ACh) menjadi kolin dan asam asetat, yaitu reaksi yang diperlukan untuk memungkinkan neuron kolinergik untuk kembali ke keadaan istirahat setelah aktivasi ${ }^{4}$. Semakin rendah kadar enzim kolinesterase dalam darah, maka semakin terdeteksi bahwa petani tersebut mengalami keracunan akibat penggunaan pestisida. Penurunan aktivitas enzim tersebut dapat mengakibatkan terganggunya sistem saraf, keracunan, hingga kematian ${ }^{4}$
Salah satu pestisida yang terkenal menghambat enzim kolinesterase adalah pestisida golongan organofosfat dan golongan karbamat ${ }^{5}$.

Hasil penelitian yang dilakukan oleh Budiawan (2014) mengenai Faktor Resiko yang Berhubungan dengan cholinesterase pada Petani Bawang Merah di Ngurensiti Pati dengan sampel yang berjumlah 50 orang dengan alat Spektrofotometri didapat hasil $50 \%$ petani dengan Kolinesterase di bawah normal ${ }^{6}$. Penelitian lain tentang kolinesterase yaitu penelitian yang dilakukan oleh Tampudu, dkk ${ }^{7}$ mengenai Gambaran Kadar Cholinesterase Darah Petani Penyemprot Pestisida di Desa Minasa Baji Kab. Maros pada 60 sampel petani didapatkan hasil 51 orang kolinesterasenya tidak normal dan 9 orang kolinesterasenya normal Masih banyaknya petani yang menggunakan pestisida untuk penyemprotan menyebabkan tingginya prevalensi angka keracunan. Sampai saat ini belum pernah dilakukan pengukuran

Meditory | ISSN Online : 2549-1520, ISSN Cetak : 2338 - 1159, Vol. 6, No. 2, Desember 2018 HIm. 108 - 115, http://ejournal.poltekkes-denpasar.ac.id/index.php/M 
Ni Kadek Meiriana Sari, Dkk., Gambaran Kadar Enzim Kolinesterase Dalam Darah Pada Kelompok Tani Mekar Nadi Di Desa Batunya Kecamatan Baturiti

kolinesterase darah terhadap masyarakat di Desa Batunya, Kecamatan Baturiti. Selain itu, di daerah tersebut sebagian besar penduduk bekerja di sektor pertanian. Penggunaan pestisida yang dilakukan secara secara terusmenerus oleh petani disana, diduga adanya residu pestisida yang tertimbun dalam darah petani. Selain itu, adanya beberapa masalah kesehatan yang dialami petani seperti pusing, mual-mual dan gatal-gatal setelah melakukan penyemprotan dengan pestisida. Mengingat angka prevalensi keracunan pestisida yang cukup tinggi pada petani yang terpapar pestisida serta adanya kemungkinan masyarakat sekitar mengalami gangguan kesehatan akibat cemaran dari pestisida. Oleh karena itu, penulis ingin melakukan penelitian mengenai "Gambaran Kadar Enzim Kolinesterase Dalam Darah Pada Kelompok Tani Mekar Nadi di Desa Batunya Kecamatan Baturiti”.

\section{METODE}

Jenis penelitian yang digunakan adalah penelitian deskriptif. Populasi dalam penelitian ini adalah anggota kelompok Tani Mekar Nadi sebanyak 30 orang. Besar sampel yang diambil sebanyak $100 \%$ dari populasi, yaitu 30 orang dengan teknik sampling jenuh. Data primer dalam penelitian ini meliputi:

1. Hasil pemeriksaan kadar enzim Kolinesterase

2. Wawancara dan observasi langsung mengenai nama, umur, pendidikan, masa kerja, lama penyemprotan, dan tindakan yang dilakukan Kelompok Tani Mekar Nadi.

\section{HASIL DAN PEMBAHASAN}

\section{Hasil}

Dalam penelitian ini yang menjadi responden adalah anggota Kelompok Tani Mekar Nadi dengan karakteristik sebagai berikut:

Meditory | ISSN Online : 2549-1520, ISSN Cetak : 2338 - 1159, Vol. 6, No. 2, Desember 2018 HIm. 108 - 115, http://ejournal.poltekkes-denpasar.ac.id/index.php/M 
Tabel 1

Karakteristik responden

\begin{tabular}{lcc}
\hline \multicolumn{1}{c}{ Karakteristik } & Jumlah & \% \\
\hline Tingkat Pendidikan & & \\
SD & 6 & 20 \\
SMP & 9 & 30 \\
SMA & 15 & 50 \\
Masa kerja & & \\
$(<5$ tahun $)$ & 3 & 10 \\
$(\geq 5$ tahun $)$ & 27 & 90 \\
Lama menyemprot & & \\
$(<3$ jam $)$ & 30 & 100 \\
$(\geq 3$ jam $)$ & - & - \\
Penggunaan APD & 10 & 33,4 \\
Lengkap $(\geq 5)$ & 20 & 66,6 \\
Tidak lengkap $(<5)$ & & - \\
Pengelolaan pestisida & - & 100 \\
Baik $(<10$ jawaban $)$ & 30 & \\
Kurang baik $(\geq 10$ jawaban $)$ & & \\
\hline
\end{tabular}

\begin{tabular}{|c|c|}
\hline \multirow{3}{*}{$\begin{array}{l}\text { Karakteristik responden } \\
\text { berdasarkan tingkat pendidikan } \\
\text { paling banyak pada tingkat }\end{array}$} & jam $(100 \%)$ pada setiap kal \\
\hline & penyemprotan, $\quad$ berdasarl \\
\hline & penggunaan Alat Pelindung \\
\hline Pendidikan SMA (50\%), berdasarkan & (APD) paling banyak respon \\
\hline lamanya masa kerja responden & tidak lengkap dalam menggun \\
\hline paling banyak pada petani yang & APD $(66,6 \%)$, dan berdasa \\
\hline bekerja $\geq 5$ tahun $(90 \%)$ & tindakan \\
\hline berdasarkan lama menyemprot & ng baik d \\
\hline 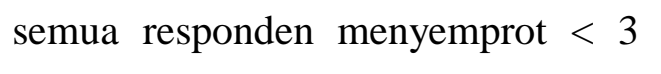 & \\
\hline
\end{tabular}

Tabel 2

Kadar enzim kolinesterase dalam darah responden

No. Katagori Jumlah Persentase

$(\%)$

\begin{tabular}{lccc}
\hline 1. & Normal & 8 & 26,7 \\
2. & Tidak Normal & 22 & 73,3 \\
\hline & Total & 30 & 100 \\
\hline
\end{tabular}

Meditory | ISSN Online : 2549-1520, ISSN Cetak : 2338 - 1159, Vol. 6, No. 2, Desember 2018 HIm. 108 -115, http://ejournal.poltekkes-denpasar.ac.id/index.php/M 


Hasil pemeriksaan kadar $\begin{aligned} & \text { yang normal sebanyak } 8 \text { orang } \\ & \text { enzim kolinesterase dalam darah }\end{aligned}$ (26,7\%).
pada Kelompok Tani Mekar Nadi
diperoleh kadar tidak normal
sebanyak 22 orang $(73,3 \%)$ dan hasil

Tabel 3

Kadar enzim kolinesterase berdasarkan karakteristik

\begin{tabular}{|c|c|c|c|}
\hline \multicolumn{4}{|c|}{ Kadar Kolinesterase } \\
\hline \multirow[t]{2}{*}{ Karakteristik } & Normal & Tidak normal & total \\
\hline & $\mathbf{n}$ & $\mathbf{n}$ & $\mathbf{n}$ \\
\hline \multicolumn{4}{|l|}{ Pendidikan } \\
\hline SD & - & 6 & 6 \\
\hline SMP & 1 & 8 & 9 \\
\hline SMA & 7 & 8 & 15 \\
\hline \multicolumn{4}{|l|}{ Lama masa kerja } \\
\hline Baru ( $<5$ tahun) & 2 & 1 & 3 \\
\hline Lama ( $\geq 5$ tahun $)$ & 6 & 21 & 27 \\
\hline \multicolumn{4}{|l|}{ Lamanya penyemprotan } \\
\hline Tidak lama $(<3$ jam $)$ & 8 & 22 & 30 \\
\hline Lama $(\geq 3$ jam $)$ & - & - & - \\
\hline \multicolumn{4}{|l|}{ Kelengkapan APD } \\
\hline Lengkap (APD $\geq 5$ ) & 4 & 6 & 10 \\
\hline Tidak lengkap (APD < 5) & 4 & 16 & 20 \\
\hline \multicolumn{4}{|l|}{ Pengelolaan pestisida } \\
\hline Kurang baik (perilaku benar $<10$ ) & 8 & 22 & 30 \\
\hline Baik (perilaku benar $\geq 10)$ & - & - & - \\
\hline \multirow{3}{*}{$\begin{array}{l}\text { a. Berdasarkan tingkat Pendidikan, } \\
\text { dari } 30 \text { responden kadar enzim } \\
\text { kolinesterase tidak normal paling } \\
\text { banyak pada tingkat pendidikan } \\
\text { SMA dan SMP }(53,4 \%) \text {. }\end{array}$} & \multicolumn{3}{|c|}{$\begin{array}{l}\text { c. Berdasarkan lama menyemprot } \\
\text { menunjukkan }(100 \%) \text { responden }\end{array}$} \\
\hline & melak & penyemprotan & \\
\hline & & lam setiap & ali \\
\hline \multirow{2}{*}{$\begin{array}{l}\text { b. Berdasarkan lamanya masa kerja } \\
\text { paling banyak responden bekerja }\end{array}$} & meny & ot dengan & \\
\hline & norme & $5,7 \%$ ) dan tidak $n$ & nal \\
\hline$\geq 5$ tahun $(90 \%)$, dengan kadar & & & \\
\hline
\end{tabular}

Maditory | ISSN Online : 2549-1520, ISSN Cetak : 2338 - 1159, Vol. 6, No. 2, Desember 2018 HIm. 108 -115, http://ejournal.poltekkes-denpasar.ac.id/index.php/M 
Ni Kadek Meiriana Sari, Dkk., Gambaran Kadar Enzim Kolinesterase Dalam Darah Pada Kelompok Tani Mekar Nadi Di Desa Batunya Kecamatan Baturiti

d. Berdasarkan penggunaan APD diperoleh responden dengan APD tidak lengkap $(66,7 \%)$, dengan kadar normal $(13,3 \%)$ dan tidak normal $(53,3 \%)$.

e. Berdasarkan tindakan pengelolaan pestisida, semua responden perilakunya kurang baik dalam pengelolaan pestisida (100\%) dengan kadar normal $(26,7 \%)$ dan tidak normal $(73,3 \%)$.

\section{Pembahasan}

\section{a. Kadar enzim cholinesterase responden}

suatu bentuk enzim dari katalis biologik di dalam jaringan tubuh yang berperan untuk menjaga agar otot-otot, kelenjar-kelenjar dan saraf bekerja secara terorganisir (Rahmawati dan Martiana, 2014). Pemeriksaan ini dilakukan dengan alat photometric analyzer dengan metode Ellman. Salah satu pestisida yang terkenal menghambat enzim kolinesterase adalah pestisida golongan organofosfat dan golongan karbamat.

Hasil penelitian kadar enzim cholinesterase dalam darah pada responden diperoleh kadar tidak normal sebanyak 22 orang $(73,3 \%)$ sedangkan hasil yang normal sebanyak 8 orang $(26,7 \%)$. Sedangkan hasil uji pada kontrol darah orang yang tidak kontak dengan pestisida ) yang menunjukkan hasil normal dengan kadar cholinesterase 3,27 U/mL. Didapatkan hasil paling banyak tidak normal pada penelitian ini disebabkan oleh beberapa faktor, yaitu seringnya petani terpapar pestisida melalui kegiatan penyemprotan selain itu berdasarkan hasil wawancara sebagian besar responden kurang lengkap dalam penggunaan APD, kurangnya pengetahuan dalam pengelolaan pestisida yang baik, dan sebagian besar responden memiliki masa kerja yang lama sebagai petani.

Meditory | ISSN Online : 2549-1520, ISSN Cetak : 2338 - 1159, Vol. 6, No. 2, Desember 2018 HIm. 108 - 115, http://ejournal.poltekkes-denpasar.ac.id/index.php/M 
Ni Kadek Meiriana Sari, Dkk., Gambaran Kadar Enzim Kolinesterase Dalam Darah Pada Kelompok Tani Mekar Nadi Di Desa Batunya Kecamatan Baturiti

b. Kadar enzim cholinesterase berdasarkan tingkat Pendidikan

Tingkat pendidikan formal merupakan tolak ukur bagi seseorang untuk lebih mudah dalam memberikan persepsi, respon, atau tanggapan mengenai segala sesuatu yang datang dari luar. ${ }^{8}$

Namun tidak berlaku dalam penelitian ini, karena tidak terdapat hubungan antara pendidikan dengan tingkat keracunan pestisida. Hal ini menunjukkan bahwa rendahnya kadar enzim kolinesterase dalam darah tidak semata-mata berhubungan dengan tingkat pendidikan seseorang, artinya rendah atau tinggi tingkat pendidikan seseorang tidak berhubungan secara langsung terhadap paparan pestisida. Kenyataan ini ditunjukkan dari hasil penelitian ini diperoleh kadar enzim kolinesterase tidak normal paling banyak ditemukan pada tingkat pendidikan SMA dan SMP yaitu masing-masing 8 orang $(26,7 \%)$, sedangkan kadar enzim kolinesterase normal diperoleh pada tingkat pendidikan SMA yaitu 7 orang $(23,3 \%)$.

\section{c. Kadar enzim cholinesterase berdasarkan masa kerja}

Beberapa penelitian menyatakan bahwa masa kerja sebagai petani merupakan faktor risiko terjadinya keracunan akibat pestisida pada petani. Dari hasil penelitian pada 30 responden kadar enzim kolinesterase dalam darah paling banyak ditemukan pada responden yang bekerja $\geq 5$ tahun yaitu sebanyak 27 orang (90\%), dengan kadar normal sebanyak 6 orang (20\%) dan tidak normal 21 orang $70(\%)$. Sedangkan yang masa kerjanya $<5$ tahun sebanyak 3 orang (10\%), dengan kadar normal 2 orang $(6,7 \%)$ dan tidak normal 1 orang $(3,3 \%)$.

Penelitian ini juga sejalan dengan penelitian yang pernah dilakukan oleh Tapudi dkk, 2010 yang menggambarkan bahwa petani yang mempunyai kadar kolinesterase darah tidak normal lebih besar pada mereka yang mempunyai masa kerja $\geq 5$ tahun. Hal ini sesuai dengan teori

Meditory | ISSN Online : 2549-1520, ISSN Cetak : 2338 - 1159, Vol. 6, No. 2, Desember 2018 HIm. 108 - 115, http://ejournal.poltekkes-denpasar.ac.id/index.php/M 
Ni Kadek Meiriana Sari, Dkk., Gambaran Kadar Enzim Kolinesterase Dalam Darah Pada Kelompok Tani Mekar Nadi Di Desa Batunya Kecamatan Baturiti

yang menyatakan bahwa semakin lama orang bekerja maka semakin tinggi pula tingkat pemaparannya.

\section{d. Kadar enzim cholinesterase} berdasarkan lama menyemprot

Semakin lama melakukan penyemprotan, maka pestisida yang terpapar akan semakin banyak. Faktor lama menyemprot pada penelitian ini menunjukkan bahwa semua responden melakukan penyemprotan $<3$ jam dalam setiap kali menyemprot dengan kadar normal sebanyak 8 orang $(26,7 \%)$ dan tidak normal sebanyak 22 orang $(73,3 \%)$. Batas maksimal lama penyemprotan yang ideal menurut Permenaker No. Per-03/Men 1986 bahwa untuk tiap satu kali kegiatan adalah 4 jam. Lama waktu penyemprot tidak berpengaruh terhadap kejadian keracunan karena penggunaan pestisida dalam waktu yang singkat telah dapat menimbulkan keracunan pada petani.

\section{e. Kadar enzim cholinesterase berdasarkan penggunaan APD}

Penggunaan APD saat penyemprotan sangat berpengaruh terhadap jumlah masuknya partikel pestisida ke dalam tubuh petani. Alat pelindung yang wajib digunakan petani antara lain: penutup kepala/topi, kacamata, masker, baju lengan panjang, sarung tangan, celana panjang dan sepatu bot ${ }^{9}$. Dari hasil penelitian diperoleh kadar enzim cholinesterase responden dengan APD tidak lengkap sebanyak 20 orang $(66,7 \%)$, dengan katagori normal 4 orang $(13,3 \%)$ dan tidak normal 16 orang $(53,3 \%)$. Sedangkan kadar enzim koolinesterase responden dengan APD lengkap sebanyak 10 orang $(33,3 \%)$, dengan kadar normal 4 orang $(13,3 \%)$ dan tidak normal 6 orang $(20 \%)$. Penelitian ini sejalan dengan

Meditory | ISSN Online : 2549-1520, ISSN Cetak : 2338 - 1159, Vol. 6, No. 2, Desember 2018 HIm. 108 - 115, http://ejournal.poltekkes-denpasar.ac.id/index.php/M 
Ni Kadek Meiriana Sari, Dkk., Gambaran Kadar Enzim Kolinesterase Dalam Darah Pada Kelompok Tani Mekar Nadi Di Desa Batunya Kecamatan Baturiti

penelitian yang dilakukan Runia (2008) bahwa responden yang menggunakan APD tidak lengkap sebagian besar mengalami keracunan akibat pestisida.

Berdasarkan penelitian di lapangan sikap petani dalam pemakaian APD banyak yang tidak lengkap karena ketidaknyamanan saat memakai APD secara lengkap.

\section{f. Kadar enzim cholinesterase berdasarkan pengelolaan pestisida}

Berdasarkan hasil wawancara mengenai tindakan yang dilakukan petani dalam pengelolaan pestisida didapatkan hasil dari 30 responden, ditemukan pada semua responden perilakunya kurang baik dalam pengelolaan pestisida, yaitu sebanyak 30 orang $(100 \%)$ dengan kadar enzim kolinesterase normal sebanyak 8 orang $(26,7 \%)$ dan tidak normal sebanyak 22 orang $(73,3 \%)$.

Risiko keracunan pestisida dapat dihindari apabila pengelolaan pestisida pada masing-masing tahap kegiatan dilakukan dengan baik dan benar, dalam arti melakukan pengelolaan pestisida dengan memperhatikan petunjuk dan aturan yang ada. Oleh karena itu penting bagi para penyemprot untuk mengenal jenis dan bahan aktif pestisida serta cara pengelolaannya ${ }^{8}$

\section{SIMPULAN DAN SARAN}

\section{Simpulan}

Berdasarkan hasil penelitian dapat disimpulkan bahwa:

1. Karakteristik responden berdasarkan tingkat pendidikan paling banyak pada tingkat Pendidikan SMA (50\%), berdasarkan lamanya masa kerja responden paling banyak pada petani yang bekerja $\geq 5$ tahun (90\%), berdasarkan lama

Meditory | ISSN Online : 2549-1520, ISSN Cetak : 2338 - 1159, Vol. 6, No. 2, Desember 2018 HIm. 108 - 115, http://ejournal.poltekkes-denpasar.ac.id/index.php/M 
Ni Kadek Meiriana Sari, Dkk., Gambaran Kadar Enzim Kolinesterase Dalam Darah Pada Kelompok Tani Mekar Nadi Di Desa Batunya Kecamatan Baturiti

menyemprot semua responden menyemprot $<3$ jam $(100 \%)$ pada setiap kali penyemprotan, berdasarkan penggunaan Alat Pelindung Diri (APD) paling banyak responden tidak lengkap dalam menggunakan APD $(66,6 \%)$, dan berdasarkan tindakan pengelolaan pestisida semua responden kurang baik dalam pengelolaan pestisida $(100 \%)$.

2. Hasil pemeriksaan kadar enzim kolinesterase pada responden diperoleh kadar tidak normal sebanyak 22 orang $(73,3 \%)$ sedangkan hasil yang normal sebanyak 8 orang $(26,7 \%)$.

3. Kadar Enzim Kolinesterase berdasarkan karakteristik, yaitu:

4. Berdasarkan tingkat Pendidikan, dari 30 responden kadar enzim kolinesterase tidak normal paling banyak pada tingkat pendidikan SMA dan SMP $(53,4 \%)$. Berdasarkan lamanya masa kerja paling banyak responden bekerja $\geq 5$ tahun (90\%), dengan kadar normal (20\%) dan tidak normal $(70 \%)$.
Berdasarkan lama menyemprot menunjukkan $(100 \%)$ responden melakukan penyemprotan $<3$ jam dalam setiap kali menyemprot dengan kadar normal $(26,7 \%)$ dan tidak normal $(73,3 \%)$. Berdasarkan penggunaan APD diperoleh responden dengan APD tidak lengkap (66,7\%), dengan kadar normal $(13,3 \%)$ dan tidak normal (53,3\%). Berdasarkan tindakan pengelolaan pestisida, semua responden perilakunya kurang baik dalam pengelolaan pestisida (100\%) dengan kadar normal $(26,7 \%)$ dan tidak normal $(73,3 \%)$.

\section{Saran}

1. Kepada Dinas Pertanian Tanaman Pangan dan Holtikultura Tabanan perlu melakukan penyuluhan untuk meningkatkan kesadaran tentang bahaya pestisida dan bagaimana cara melindungi diri dari pajanan pestisida sehingga tidak menimbulkan dampak negatif jangka panjang.

Meditory | ISSN Online : 2549-1520, ISSN Cetak : 2338 - 1159, Vol. 6, No. 2, Desember 2018 HIm. 108 -115, http://ejournal.poltekkes-denpasar.ac.id/index.php/M 
Ni Kadek Meiriana Sari, Dkk., Gambaran Kadar Enzim Kolinesterase Dalam Darah Pada Kelompok Tani Mekar Nadi Di Desa Batunya Kecamatan Baturiti

2. Kepada anggota Kelompok Tani diharapkan menggunakan Alat Pelindung Diri (APD) yang lengkap selain itu dapat melakukan tindakan pengelolaan pestisida dengan baik dan benar.

3. Kepada peneliti selanjutnya diharapkan dapat melanjutkan penelitian ini dengan mengukur tingkat keracunan pestisida pada petani sayur penyemprot dalam wilayah dan populasi yang lebih luas sehingga didapatkan gambaran sebaran keracunan yang terjadi dan dapat juga diangkat karakteristikkarakteristik lain yang mungkin berperan sebagai faktor risiko yang penting dan belum diketahui

\section{DAFTAR PUSTAKA}

1. Kementrian Pertanian. 2012. Direktorat Jendral Prasarana dan Sarana Pertanian. Direktorat Pupuk dan Pestisida Kementerian Pertanian.

2. Priyanto. 2010. Toksikologi, Mekanisme, Terapi Antidotum, dan Penilaian Resiko, Alih bahasa Hadi sunaryo, Apt, Ms. (ed.). Jawa Barat: Leskonfi.
3. Rahmawati dan Martiana. 2014. Pengaruh Faktor Karakteristik Petani Dan Metode Penyemprotan Terhadap Kadar Kolinesterase. The Indonesian Journal of Occupational Safety, Health, and Environment, 1(1), pp. 85-94.

4. Krsti, D. Z., Lazarevi, T. D., Bond, A. M. and Vasi, V. M. 2013. Acetylcholinesterase Inhibitors: Pharmacology and Toxicology. pp. 315-335. Available at: https://www.ncbi.nlm.nih.gov/pmc /articles/PMC3648782/.

5. Lu, F. C. 2010. Toksikologi Dasar. Alih bahasa Edi, N. Jakarta: Universitas Indonesia (UI-Press).

6. Budiawan, R. A. 2014. Faktor Risiko Yang Berhubungan Dengan Cholinesterase Pada Petani Bawang Merah Di Ngurensiti Pati, Unnes Journal of Public Health, 3(1), pp. 1-11. Available at: https://journal.unnes.ac.id/nju/inde x.php/kemas/article/download/282 2/2878\%0A.

7. Tampudu Sylpanus, S, R. S. and Rahim Muh. Rum. 2010. Kadar Cholinesterase Darah Petani Penyemprot Pestisida, 6(2). Available at: https://media.neliti.com/media/pub lications/27378-ID-gambarankadar-cholinesterase-darah-petanipenyemprot-pestisida-di-desaminasa-b.pdf

8. Kurniasih, S. A., Setiani, O. and Nugraheni, S. A. 2013. Faktorfaktor yang Terkait Paparan Pestisida dan Hubungannya dengan Kejadian Anemia pada Petani Hortikultura di Desa

Maditory | ISSN Online : 2549-1520, ISSN Cetak : 2338 - 1159, Vol. 6, No. 2, Desember 2018 HIm. 108 - 115, http://ejournal.poltekkes-denpasar.ac.id/index.php/M 
Ni Kadek Meiriana Sari, Dkk., Gambaran Kadar Enzim Kolinesterase Dalam Darah Pada Kelompok Tani Mekar Nadi Di Desa Batunya Kecamatan Baturiti

Gombong Kecamatan Belik

Kabupaten Pemalang Jawa

Tengah Factors Related to

Pesticides Exposure and Anemia on Horticultural Farmers In

Gombo. Jurnal Kesehatan Lingkungan Indonesia, 12(2), pp. 132-7.

9. Runia, Y. A. 2008. Faktor-Faktor Yang Berhubungan Dengan Keracunan Pestisida Organofosfat, Karbamat Dan Kejadian Anemia Pada Petani Hortikultura Di Desa Tejosari Kecamatan Ngablak Kabupaten Magelang, Testis, pp. 1-73. Available at: https://core.ac.uk/download/pdf/11 717243.pdf.

Maditory | ISSN Online : 2549-1520, ISSN Cetak : 2338 - 1159, Vol. 6, No. 2, Desember 2018 HIm. 108 - 115, http://ejournal.poltekkes-denpasar.ac.id/index.php/M 